\title{
Coulisses
}

Revue de théâtre

6 | Printemps 1992

Varia

\section{Le Jardin des délices}

\section{(2) OpenEdition}

1 Journals

Édition électronique

URL : http://journals.openedition.org/coulisses/1889

DOI : $10.4000 /$ coulisses.1889

ISSN : 2546-9460

\section{Éditeur}

Presses universitaires de Franche-Comté

\section{Édition imprimée}

Date de publication : 1 juin 1992

ISSN : 1150-594X

\section{Référence électronique}

"Le Jardin des délices », Coulisses [En ligne], 6 | Printemps 1992, mis en ligne le 15 mars 2019,

consulté le 31 octobre 2019. URL : http://journals.openedition.org/coulisses/1889; DOI : 10.4000/

coulisses. 1889

Ce document a été généré automatiquement le 31 octobre 2019

Coulisses 


\section{Le Jardin des délices}

"Le Jardin des délices» a été présenté le 24 avril 92 à Besançon, salle Battant, après avoir été joué à l'Université de Bordeaux (4 avril) dans le cadre de la Semaine du Théâtre à l'Université et à Edimburgh (11 avril) au Festival International de Théâtre à l'Université.

1 Le Jardin des délices est une création collective du Théâtre Universitaire de FrancheComté sur le thème de la poésie, sa nature, son langage. A la fois parcours initiatique et florilège de poèmes, le spectacle a été présenté pour la première fois en juin 1991 dans la cour Chifflet de la Faculté des Lettres, trois jardins à la française qui se succèdent, limités par des marches, des grilles, des haies. Les questions fondatrices : Qu'est-ce que la poésie? Que représente-t-elle aujourd'hui ? Peut-on la mettre en scène? donnent l'esprit de la création. Le spectacle a ensuite été revu, recréé en vue de sa diffusion en salle. Les jardins ont fait place à la course vagabonde imaginaire de comédiens se déplaçant de villages en villages afin de porter à tous la force du message poétique.

Que d'imagination! Tout bouge, tout est jeu, tout est joie! Les douze comédiens jonglent avec les mots, chantent, déclament, rythment les mots, les mouvements, dansent... Le ton est juste, assuré, passionné; le visage est froid puis resplendissant; l'œil est éteint puis brille, fixe la salle, cligne et déclenche une avalanche de rires (...).

Les éléments du décor sont simples : des valises qui renferment des trésors, des livres de poèmes, une grande bâche qui deviendra simultanément toile des mots de bonheur, robe à traîne d'une muse fantastique, écran de télévision, nappe et couverture. Les comédiens ne semblent pas suivre la mise en scène de Joseph Melcore tant leurs mouvements sont spontanés, leurs mots assurés, leurs sourires et leurs clins d'œil subtils. Ne cherchez pas d'histoire, il n'y en a pas. Tout n'est qu'associations d'images et de mots. Ces mots qui seront récités dans un cirque de livres placés circulairement, clamés par une géante, susurrés par un dormeur, vomis par une brute en d'affreux borborygmes. La poésie ne se métamorphose pas : elle est métamorphose. Tout dans la pièce est prétexte à sa présence, à son apparition soudaine, et elle s'insinue partout pour gagner le cœur du public.

J. Erny

Le Bien Public de Dijon (16/04/92) 
Le Jardin des délices, troupe du Théâtre Universitaire de Franche-Comté

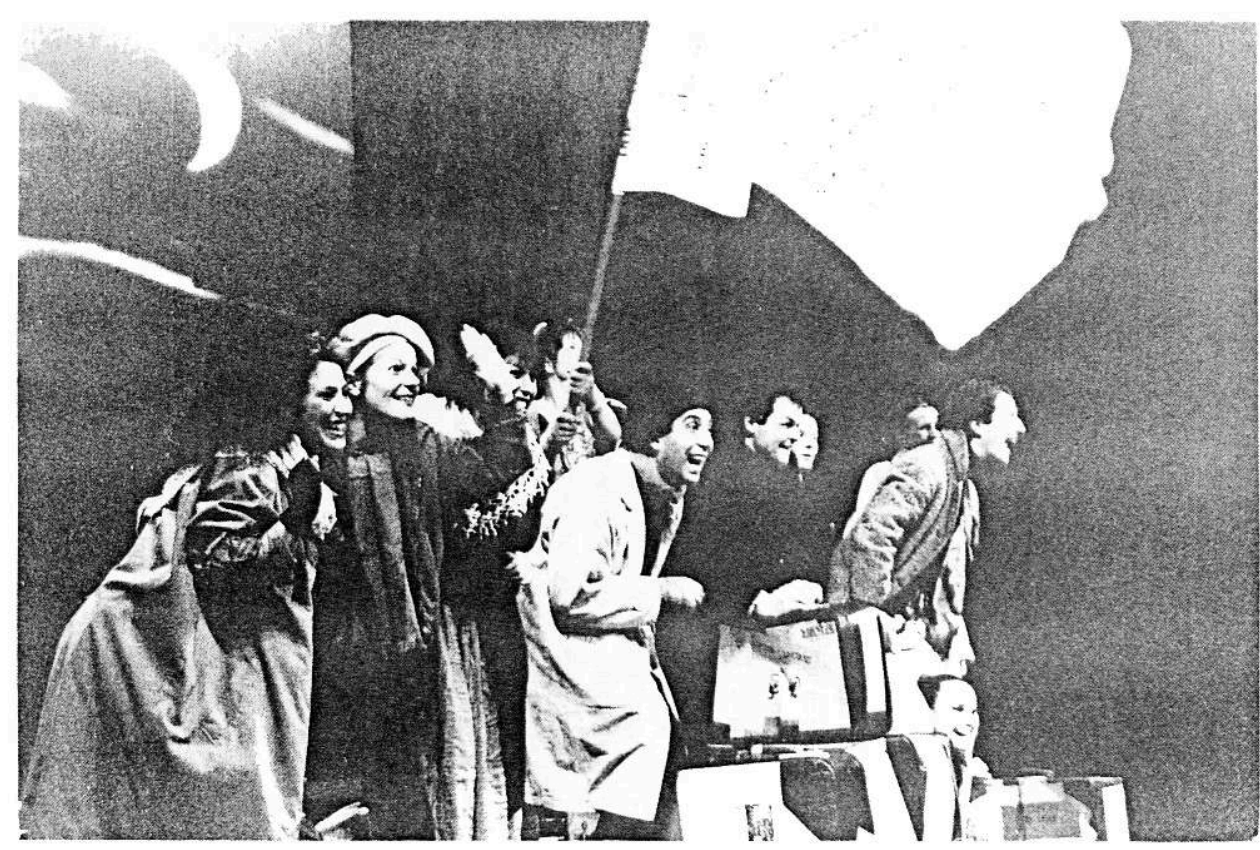

